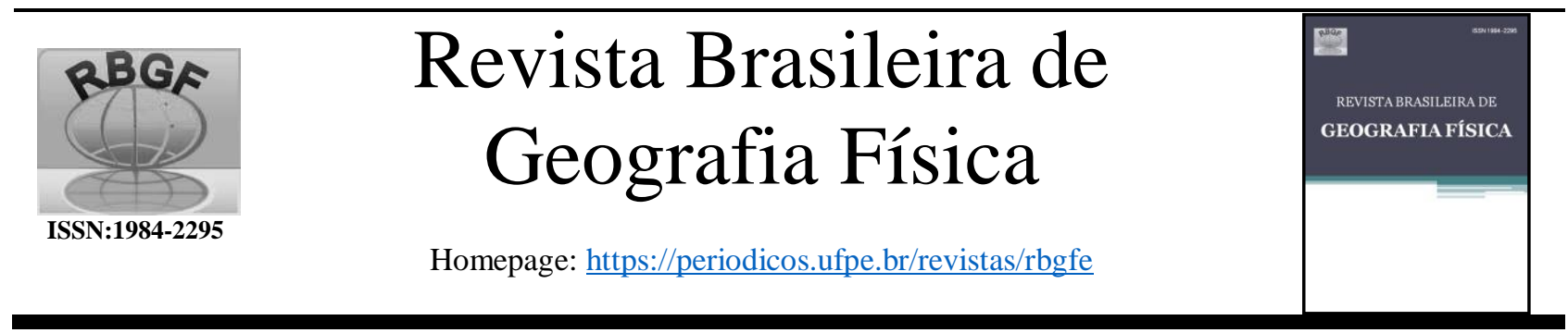

\title{
Diagnóstico do Licenciamento Ambiental da Carcinicultura no estado do Rio Grande do Norte, Brasil
}

\author{
Iáskara Michelly de Medeiros Silveira ${ }^{2}$, Daniele Bezerra Dos Santos ${ }^{4}$, Franklin Roberto da Costa ${ }^{3}$, Rodrigo \\ Herico Rodrigues de Melo Soares, Tarcísio Augusto Gonçalves Junior ${ }^{3}$, , Cibele Soares Pontes ${ }^{1}$
}

\begin{abstract}
${ }^{1}$ Dra. em Psicobiologia, Docente da Unidade Acadêmica Especializada em Ciências Agrárias (EAJ - UFRN). RN 160 - Km 03 - Distrito de Jundiaí Macaíba/RN. CEP: 59280-000 | Cx Postal 07. cibelepontes.ufrn@yahoo.com.br (autora correspondente). ${ }^{2}$ Mestre em Desenvolvimento e Meio Ambiente pela Universidade Federal do Rio Grande do Norte (PRODEMA - UFRN). iaskarasilveira@ hotmail.com. ${ }^{2}$ Mestre em Desenvolvimento e Meio Ambiente (PRODEMA - UFRN), Docente da Unidade Acadêmica Especializada em Ciências Agrárias (EAJ - UFRN). tarcigastro@gmail.com. ${ }^{4}$ Dr. em Desenvolvimento e Meio Ambiente (PRODEMA - UFRN), Docente na Universidade Estadual do RN (UERN). franklincosta@ uern.br. ${ }^{5}$ Dra. em Psicobiologia, Docente do Instituto Federal de Educação e Tecnologia do RN - Pau dos Ferros (IFRN). danielebezerra@ gmail.com.
\end{abstract}

Artigo recebido em 27/05/2019 e aceito em 24/12/2019

\begin{abstract}
R E S U M O
Em função do crescimento desordenado da carcinicultura no Nordeste do Brasil, nesta pesquisa foi realizado um levantamento dos licenciamentos ambientais voltados à carcinicultura do Estado do Rio Grande do Norte, ao longo da década de 2005 a 2015, referente ao número de empreendimentos licenciados por ano, porte dos empreendimentos por tipos de licenças outorgadas e regiões com maior densidade de fazendas de carcinicultura. A pesquisa foi realizada através de avaliação documental, com dados cedidos pelo Instituto de Desenvolvimento Sustentável e Meio Ambiente (IDEMA, 2016), e embasado nas legislações nacionais e estaduais pertinentes à área de estudo. No total, foram analisadas 698 licenças, sendo a maioria das fazendas de porte médio e solicitantes de licenças de operação, havendo uma maior concentração de empreendimentos de diferentes portes no litoral Sul do estado. Evidenciou-se uma grande quantidade de fazendas $(64,18 \%)$ com solicitação de licenças atrasadas, além da constatação de que o maior número de licenças foi expedido no período em que mais ocorreram problemas de ordem ambiental e econômica na atividade.

Palavras-chave: Estudos ambientais. Aquicultura. Camarão. Vulnerabilidade ambiental.
\end{abstract}

\section{Environmental Licensing diagnosis of Srimp farming in the state of Rio Grande do Norte, Brazil}

\begin{abstract}
A B S T R A C T
\section{Introdução}

A carcinicultura se configura como a atividade da aquicultura que mais se expandiu nos últimos anos no mundo, devido ao esgotamento dos bancos naturais de recursos pesqueiros (Reis,
\end{abstract}

In this article, a survey was made regarding the environmental licensing of shrimp farming in Rio Grande do Norte, during the decade between 2005 to 2015, in relation to the number of enterprises licensed per year, size of enterprises by type of licenses granted and regions with higher density of shrimp farms. The research was done through documentary evaluation, with data provided by the Institute for Sustainable Development and Environment (IDEMA). A total of 698 licenses were identified, with the majority of medium-sized farms and applicants for operating licenses, with a higher concentration of micro, small, medium and large ports in the southern coast of the state. A large number of farms with a request for delayed licenses $(64,18 \%)$ were evidenced, in addition to the finding that the highest number of licenses was issued in the period in which there were more economic and environmental problems in the activity.

Keywords: Environmental studies. Aquaculture. Shrimp. Environmental vulnerability.

2008). No ano de 2014, 73,8 milhões de toneladas da produção aquícola mundial foi oriunda de criatórios e desta produção, a de camarões marinhos contribuiu com 26,7 milhões de toneladas $(36,18 \%)$ (FAO, 2016).

A região brasileira mais propicia para a atividade de carcinicultura é o Nordeste, devido às condições climáticas ideais para a principal espécie 
cultivada, o camarão marinho Litopenaeus vannamei. Esta espécie se desenvolve bem em ambientes aquáticos com salinidade variando de 15 a $30 \mathrm{ppt}$, com grande incidência solar e temperaturas entre $23^{\circ} \mathrm{C}$ e $30^{\circ} \mathrm{C}$. Nesse caso, as condições climáticas constantes nesta região permitem que a carcinicultura marinha constitua uma das suas principais atividades (Salim, 2002). Atualmente, os principais estados produtores são o Ceará e o Rio Grande do Norte (Kubitza, 2015).

Rocha (2011) afirma que, a despeito de todos os predicados naturais e do excepcional desenvolvimento apresentado pelo setor entre 1997 e 2003, a carcinicultura brasileira enfrentou, entre 2004 e 2009, desafios que afetaram o seu crescimento global, sendo o principal deles a incidência do Vírus da Mionecrose Infecciosa (IMNV). Além disso, no ano de 2005, os Estados Unidos, que era o principal país importador do camarão brasileiro na época, acusou o Brasil e outros países da prática de "dumping”, por haver incentivos governamentais para que o camarão importado pelos EUA chegasse no mercado com preço inferior ao oferecido pelos produtores locais, havendo, então, uma sobretaxa do produto brasileiro.

De acordo com Rocha (2011), o desempenho do setor entre 2004 e 2009 sofreu uma redução significativa: (1) na produção, que caiu de 90.190 ton para 65.000 ton $(-22,4 \%)$; (2) na produtividade que passou de $6.083 \mathrm{~kg} / \mathrm{ha} /$ ano para $3.514 \mathrm{~kg} / \mathrm{ha} / \mathrm{ano}(-42,23 \%)$, (3) nas exportações que foram reduzidas de 58.455 ton para 5.728 ton $(-90,2 \%)$. Esse cenário pode ter interferido, cronologicamente, nos pedidos de licenciamento da carcinicultura aos órgãos ambientais competentes.

A atividade carcinicultura, que se estabelece principalmente em áreas de estuários e costeiras, pode trazer sérios problemas ambientais não só para a região de entorno como para o próprio empreendimento, uma vez que a degradação desses ecossistemas tem como consequência a proliferação de epidemias que podem causar drásticas quedas na produção aquícola, gerando perdas econômicas consideráveis (Paez-Osuna, 2001). No que diz respeito aos danos ambientais, Tahim (2019) elenca entre os principais impactos: 1) Degradação e perdas de áreas de mangues; 2) Alterações de regime hidrológico de rios e estuários; 3) Poluição por descarte de efluentes contendo resíduos orgânicos e inorgânicos; e 4) Depleção de estoques pesqueiros pela degradação do habitat, alteração da cadeia alimentar, introdução de espécies não nativas ou patogênicas.
Esse não é um problema exclusivo do estado do Rio Grande do Norte ou ainda do Nordeste do Brasil. Sousa et al. (2016) ressaltam que, no Piauí, as áreas de carcinicultura estão ocupando os espaços arenosos em torno dos manguezais (região denominada de vegetação apicum), que é entendida como parte da sucessão natural do manguezal para outras comunidades vegetais. Sousa et al. (2017) relatam que os problemas ligados à aquicultura no estado de Pernambuco estão relacionados à presença de fazendas de carcinicultura localizadas entre resquícios florestais de mata atlântica e Mangue e, como resultado, a vegetação é suprimida em detrimento da instalação dos viveiros, interferindo qualitativamente na redução de organismos vivos desse sistema ecológico. Goularti Filho e Ronçani (2018) discutem questões referentes aos frágeis mecanismos regulatórios frente à expansão acelerada das atividades econômicas e lucrativas da carcinicultura no estado de Santa Catarina.

Dessa maneira, faz-se necessária a cobrança de medidas de controle desses empreendimentos com o objetivo de minimizar impactos negativos ao meio em que estão alojados. Uma das formas mais recorrente e prevista em lei de controle de qualquer empresa é o licenciamento ambiental. A Política Nacional do Meio Ambiente (1981) criou alguns recursos para evitar danos ao meio ambiente e a sociedade, sendo um deles o licenciamento ambiental, instrumento que foi regularizado na Resolução CONAMA $\mathrm{n}^{\circ}$ 237/1997, onde é definido como:

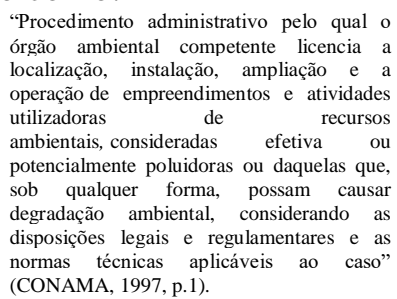

Para cada etapa do processo de licenciamento ambiental, obrigatório para qualquer atividade utilizadora de recursos ambientais, se faz necessário a obtenção de licença específica. De acordo com a Resolução CONAMA no 237/1997, essas licenças são: a) licença prévia (LP) - para a fase de planejamento de um empreendimento ou atividade; b) licença de instalação (LI) - para a construção; c) licença de operação (LO) - para início do funcionamento. Além das já citadas, no estado do Rio Grande do Norte, o Instituto de Desenvolvimento Sustentável e Meio Ambiente (IDEMA) pode expedir ainda outros quatro tipos de licenças que são regulamentadas pela Lei 
Complementar Estadual $n^{\circ} 272$, de 3 de março de 2004:

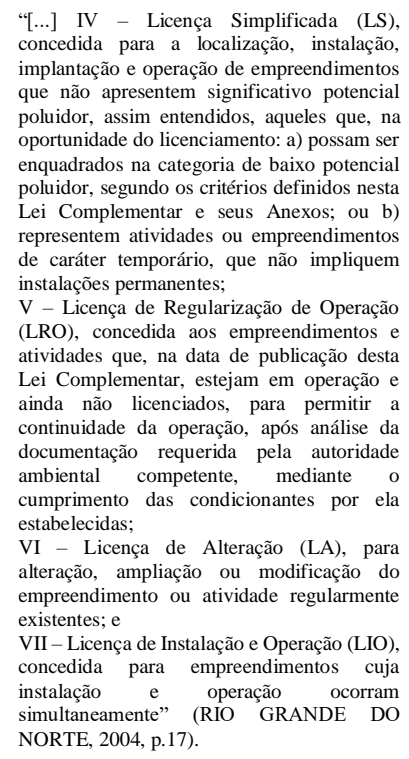

Uma das primeiras legislações específica para a regulamentação da carcinicultura no Brasil foi a resolução CONAMA no $312 / 2002$, que trata do licenciamento de empreendimentos de carcinicultura em zona costeira. Desde então, ficou proibida a instalação de fazendas de camarão nas áreas de manguezais, que passaram a ser consideradas áreas de proteção permanente (APP). Um dos impasses causados por esta resolução foi a não caracterização das áreas de apicum e salgado como pertencentes ao ecossistema manguezal, uma vez que estas constituem a região de transição entre o mangue e a vegetação local, sendo, portanto, considerada uma área de preservação essencial para proteção desse ecossistema. Para alguns órgãos ambientais estaduais, a falta de especificação na lei exclui a necessidade de resguardar esses ambientes. Já outros proíbem a instalação de empreendimentos nesses locais, gerando maus entendidos e discordâncias entre empresários, órgãos ambientais, sociedade civil, ambientalistas, cientistas e o poder legislativo (RIBEIRO et al., 2014).

O novo Código Florestal Brasileiro, promulgado em 2012, veio abordando o tema pela primeira vez, trazendo as seguintes definições:

$$
\begin{aligned}
& \text { XIV - salgado ou marismas tropicais } \\
& \text { hipersalinos: áreas situadas em regiões com } \\
& \text { frequências de inundações intermediárias } \\
& \text { entre marés de sizígias e de quadratura, com } \\
& \text { solos cuja salinidade varia entre } 100 \text { (cem) e } \\
& 150 \text { (cento e cinquenta) partes por } 1.000 \text { (mil), } \\
& \text { onde pode ocorrer a presença de vegetação } \\
& \text { herbácea específica; } \\
& \text { XV - apicum: áreas de solos hipersalinos } \\
& \text { situadas nas regiões entre marés superiores, } \\
& \text { inundadas apenas pelas marés de siź́gias, que } \\
& \text { apresentam salinidade superior a } 150 \text { (cento e } \\
& \text { cinquenta) partes por } 1.000 \text { (mil), desprovidas } \\
& \text { de vegetação vascular; (CONAMA,2012, p. } \\
& \text { 4) }
\end{aligned}
$$

A utilização de salgados e apicuns passou a ser permitida nacionalmente para implantação de fazendas de criação de camarões, condicionado a que fossem seguidos alguns requisitos como:

$$
\begin{aligned}
& \text { I - área total ocupada em cada Estado não } \\
& \text { superior a } 10 \% \text { (dez por cento) dessa } \\
& \text { modalidade de fitofisionomia no bioma } \\
& \text { amazônico e a } 35 \% \text { (trinta e cinco por cento) } \\
& \text { no restante do País, excluídas as ocupações } \\
& \text { consolidadas que atendam ao disposto no } \$ \\
& \text { 6o deste artigo; } \\
& \text { II - salvaguarda da absoluta integridade dos } \\
& \text { manguezais arbustivos e dos processos } \\
& \text { ecológicos essenciais a eles associados, bem } \\
& \text { como da sua produtividade biológica e } \\
& \text { condição de berçário de recursos pesqueiros; } \\
& \text { III - licenciamento da atividade e das } \\
& \text { instalações pelo órgão ambiental estadual, } \\
& \text { cientificado o Instituto Brasileiro do Meio } \\
& \text { Ambiente e dos Recursos Naturais } \\
& \text { Renováveis - IBAMA e, no caso de uso de } \\
& \text { terrenos de marinha ou outros bens da União, } \\
& \text { realizada regularização prévia da titulação } \\
& \text { perante a União; } \\
& \text { IV - recolhimento, tratamento e disposição } \\
& \text { adequados dos efluentes e resíduos; } \\
& \text { V - garantia da manutenção da qualidade da } \\
& \text { água e do solo, respeitadas as Áreas de } \\
& \text { Preservação Permanente; e } \\
& \text { VI - respeito às atividades tradicionais de } \\
& \text { sobrevivência das comunidades locais. } \\
& \text { (CONAMA, 2012, p. 11) }
\end{aligned}
$$

Essa permissão levou a uma serie de discussões na sociedade, uma vez que esses locais são pouco estudados e, portanto, não se sabe a verdadeira extensão dos danos em longo prazo e como podem afetar a biota local e marinha.

A partir da constituição do novo código florestal, criou-se uma nova legislação estadual, específica para o cultivo de camarão no RN, com a aprovação da Lei Estadual no 9.978/2015, de 09 de setembro de 2015, mais conhecida como a Lei Governador Cortez Pereira. Essa lei passou a isentar de qualquer punição ou cobrança do Adicional por Tempo de Atividade Irregular a implantação de empreendimentos que tenham ocorrido anterior a 22 de julho de 2008 , desde que devidamente comprovado pelo empreendedor, em área que atualmente seja legalmente considerada como apicum e salgado.

A identificação do porte do empreendimento é um dos dados primordiais para a emissão das licenças. Na legislação estadual $n^{\circ}$ 9.978/2015, são estabelecidas 05 (cinco) categorias de empreendimentos de acordo com o tamanho (em hectare) da área de cultivo, considerando-se a somatória da área inundada produtiva, excluídos os canais de abastecimento, reservatórios e bacia de sedimentação, sendo assim divididos:

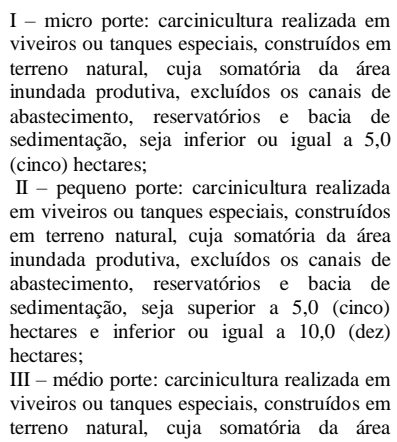

Silveira, I.M. M., Santos, D.B., Costa, F.R., Soares, R. H. R.M, Gonçalves Junior, T.A., Pontes, C.S. 


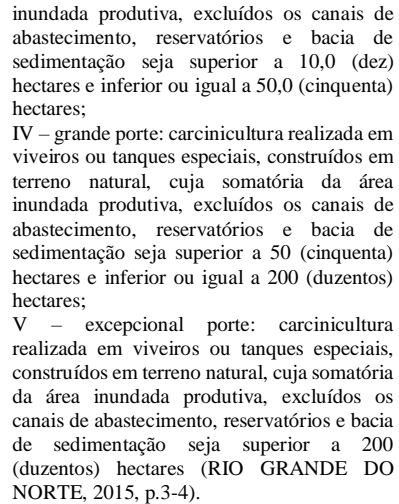

Ribeiro et al. (2014) ressaltam que o estabelecimento desses pré-requisitos em lei (tanto do código florestal como da Lei Cortez Pereira), não garante que eles sejam atendidos e nem tampouco impede que o cultivo se estenda para as áreas de manguezais, já que os órgãos ambientais responsáveis normalmente não possuem um esquema de fiscalização pontual e frequente.

Neste sentido, trabalhos que visem verificar dados acerca do licenciamento da carcinicultura no estado do Rio Grande Norte são importantes para o entendimento dos possíveis impactos causados por esta atividade, apontando a necessidade do licenciamento ambiental, pelos órgãos competentes, como busca da sustentabilidade necessária para o seu desenvolvimento.

Dessa forma, o presente artigo visa realizar uma avaliação da situação do licenciamento ambiental da carcinicultura do RN ao longo de 10 anos (2005-2015) com relação ao número de empreendimentos licenciados por ano, porte dos empreendimentos por tipos de licenças e as regiões com maior densidade de fazendas de carcinicultura.

\section{Material e métodos}

Essa pesquisa foi realizada através da investigação de documentos relativos aos processos de licenciamento ambiental concedidos, entre os anos de 2005 a 2015, para as fazendas de carcinicultura no estado do Rio Grande do Norte. Os documentos foram obtidos junto ao órgão ambiental estadual responsável pela liberação dessas licenças, o Instituto de Desenvolvimento Sustentável e Meio Ambiente (IDEMA-RN).
Foram avaliados os dados de concessão dos tipos de licença necessários para a avaliação (Licença Prévia), estabelecimento (Licença de Instalação) e funcionamento (Licença de Operação) do empreendimento, além dos tipos de licenças especiais que são expedidas somente no estado do Rio Grande do Norte que são regulamentadas pela Lei Complementar Estadual $n^{\circ}$ 272/04: Licença Simplificada, Licença de Regularização de Operação, Licença de Alteração e Licença de Instalação e Operação.

As licenças concedidas foram discriminadas ao longo de 10 (dez) anos (2005 a 2015), organizadas em função do tipo de licença, tamanho das fazendas e localidade de origem, além da observação da quantidade de empreendimentos que renovaram a licença após o tempo de vigência da anterior, para tanto, sendo levadas em consideração somente as licenças referentes aos empreendimentos ligados à fase de crescimento $\mathrm{e}$ engorda do camarão, desconsiderando assim, os dados referentes à larvicultura e ao beneficiamento do produto final.

Para organização e apresentação dos dados referentes às licenças emitidas utilizou-se estatística descritiva, com gráficos de barras referentes à quantidade de licenças emitidas de cada tipo por ano. Os gráficos descritivos da localização dos empreendimentos e suas licenças foram construídos através da utilização do Programa SIG QGIS Essen 2.14. Os dados foram apresentados e discutidos em função da legislação nacional e estadual pertinentes à atividade de carcinicultura.

\section{Resultados e discussão}

Com base nos dados obtidos junto ao órgão ambiental, foi constatado que entre os anos de 2005 a 2015, foram concedidas 698 licenças no total, distribuídas entre 06 (seis) modalidades: Licença Prévia, Licença de Instalação, Regularização de Operação, Licença Simplificada, Licença de Operação, e Licença de Alteração. Referente ao número de licenças emitidas por ano, pôde-se observar que o ano de 2006 apresentou a maior quantidade de expedições, com 88 licenças, seguido pelos anos de 2007 e 2011 com 83 licenças (Figura 1). 


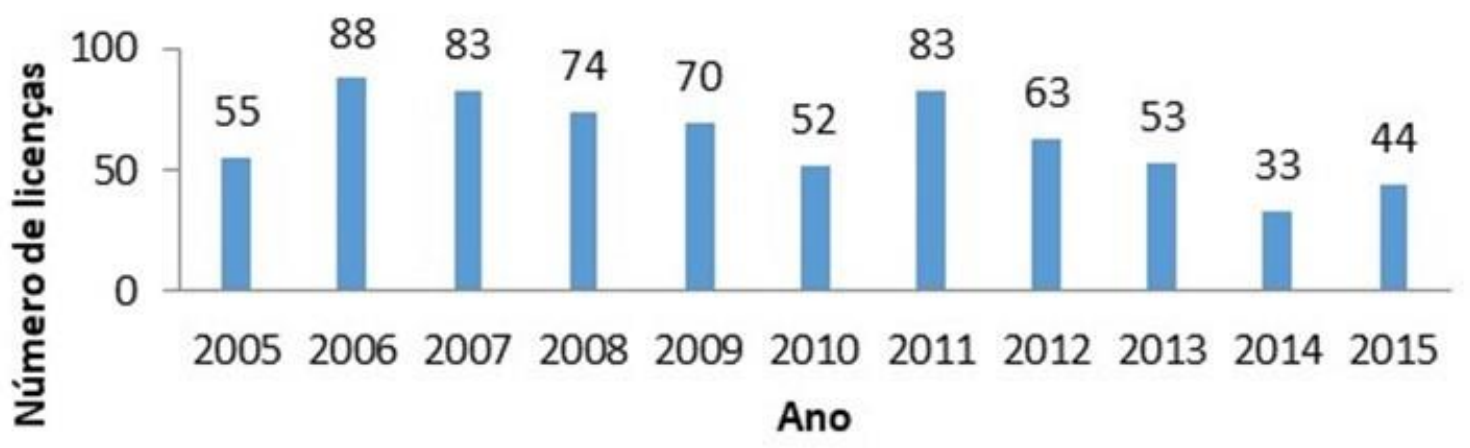

Figura 1. Número total de licenças expedidas pelo Instituto de Desenvolvimento Sustentável e Meio Ambiente (IDEMA) nos anos de 2005 a 2015. Fonte: Pesquisa Documental - IDEMA - RN, 2016.

No ano de 2015, havia uma expectativa do aumento na emissão de licenças, devido à determinação da Lei Cortez Pereira, que passou a permitir a legalização de fazendas de micro porte instaladas em áreas consideradas de apicum e salgado. Essa expectativa se deu, também, em função da exigência do atestado de conformidade ambiental (licenciamento) para acesso a linhas de financiamento no sistema bancário. Ou seja, a liberação decorrente da promulgação da lei propiciaria aos produtores maiores oportunidades de obtenção de linhas de crédito. No entanto, observou-se um aumento menor que o esperado, com um aumento de apenas 33\% do ano anterior (2014), passando de 33 para 44 licenças.

No que se refere aos tipos de licenças outorgadas, observou-se que foram expedidas 16 Licenças Prévias (LP) pelo Instituto de Desenvolvimento Sustentável e Meio Ambiente (IDEMA). Entre os anos analisados, 2011 apresentou a maior quantidade, com 4 licenças liberadas, sendo todas para empreendimentos de porte médio. Os anos de 2005, 2007, 2008, 2009 e 2014 não apresentaram nenhuma emissão desse tipo de licença (Figura 2).

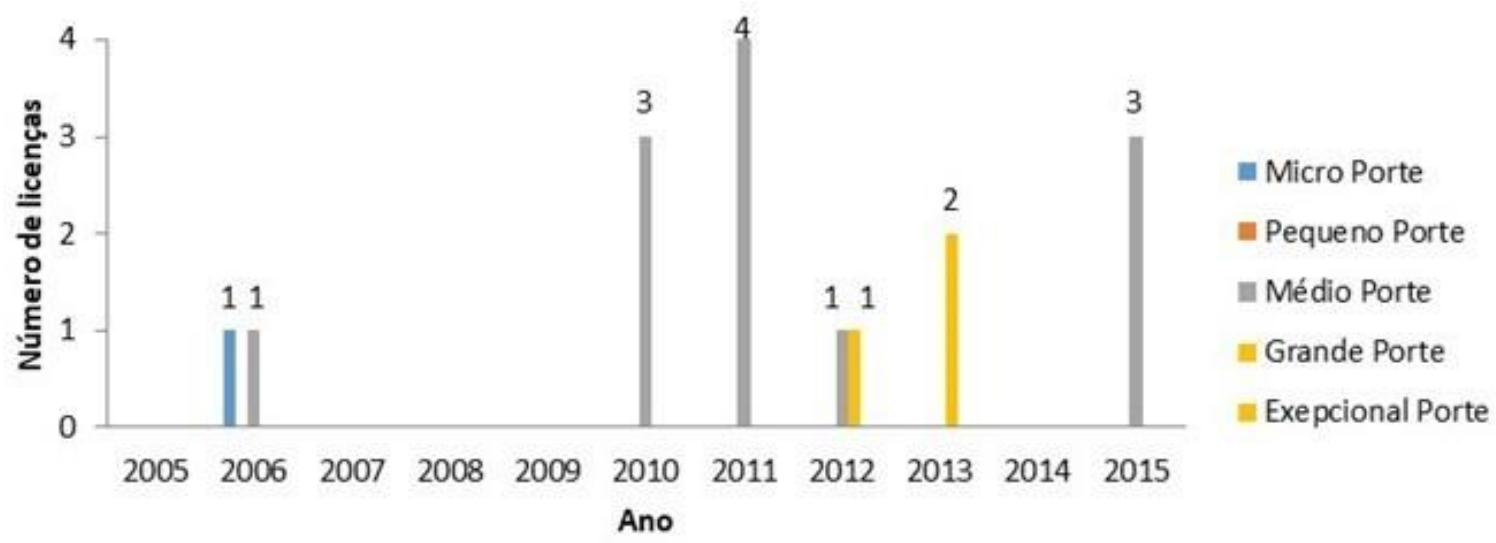

Figura 2. Licenças Prévias expedidas pelo Instituto de Desenvolvimento Sustentável e Meio Ambiente (IDEMA) entre os anos de 2005 a 2015 em razão do porte do empreendimento (Lei ${ }^{\circ}$ 9.978/2015). Fonte: Pesquisa Documental - IDEMA - RN, 2016.

As áreas de ocorrência desse tipo de licença estão distribuídas igualmente no estado do RN (Figura 3). A quantidade de licenças expedidas por cidades foram: Porção oriental: São José de Mipibú
(3), Nísia Floresta (2), Ceará - Mirim (1), Extremoz (1) e Arês (1); Porção setentrional: Pendências (2), Mossoró (1), Carnaubais (1), Macau (1), Galinhos (1), Jandaíra (1) e Guamaré (1). 

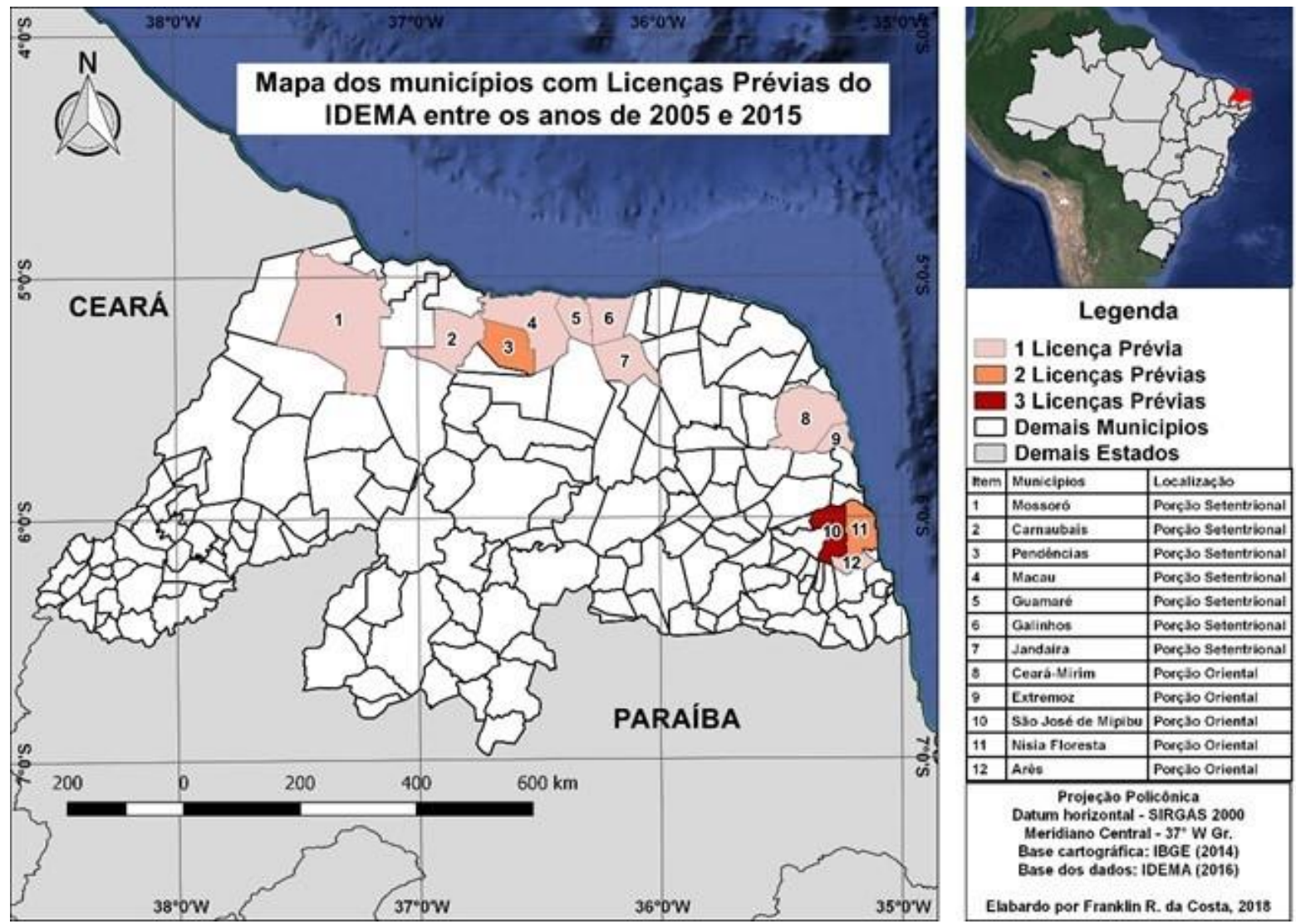

Figura 3. Representação espacial dos municípios detentores e o número de Licenças Prévias expedidas para a carcinicultura entre os anos de 2005 e 2015, de acordo com dados do Instituto de Desenvolvimento Sustentável e Meio Ambiente (IDEMA). Fonte: Pesquisa Documental - IDEMA - RN, 2016.

Com relação às Licenças de Instalação (LI), foram emitidas 26 no estado durante os 11 anos analisados, tendo como predominante o porte médio, com 18 licenças. $\mathrm{O}$ ano com maior quantidade de emissões de LI foi em 2006, com 5 licenças entre viveiros de pequeno, médio e grande porte. $\mathrm{O}$ ano de 2008 não apresentou concessões de LI (Figura 4).

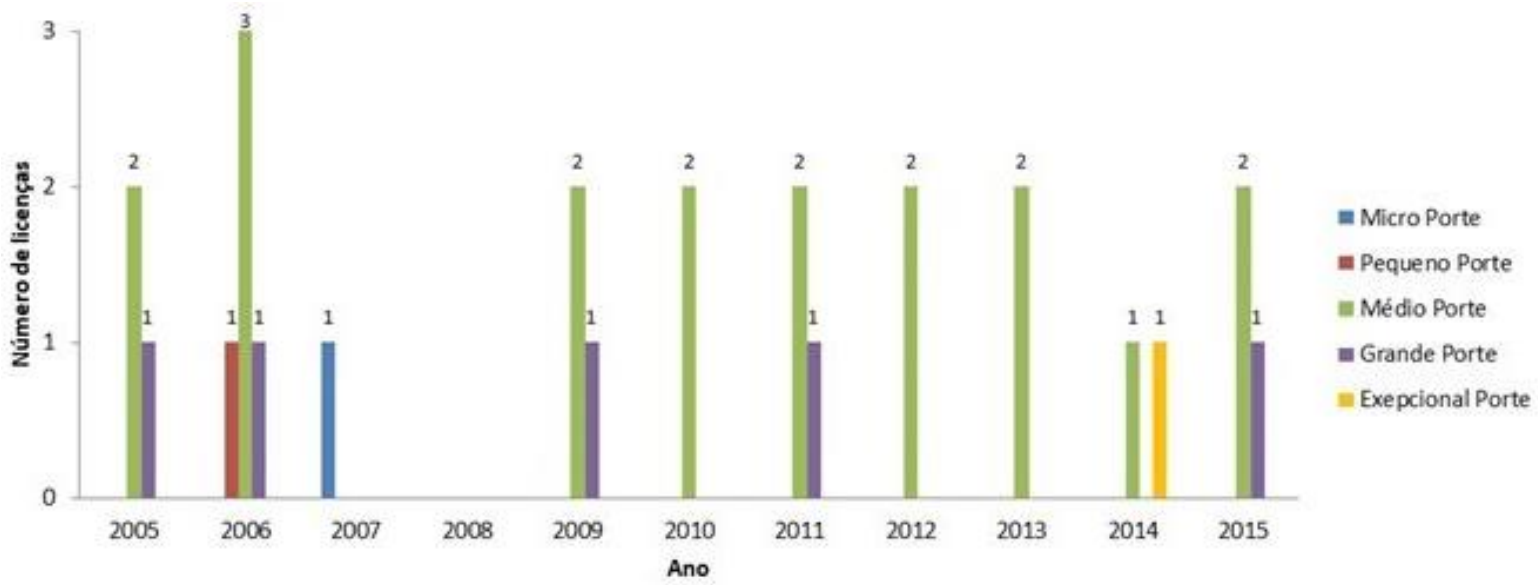

Figura 4. Licenças de Instalação expedidas pelo Instituto de Desenvolvimento Sustentável e Meio Ambiente (IDEMA) entre os anos de 2005 a 2015 em razão do porte do empreendimento (Lei no 9.978/2015).

Em relação às renovações, foram identificadas 5 (cinco) licenças desse tipo, sendo 4 (quatro) no ano de 2006 e 1(um) em 2005. Esse fato parece estranho pois, segundo informações do IDEMA, “apenas as Licenças Simplificadas e de
Operação (LS e LO) são passíveis de renovação". Dessa forma, acredita-se que essas outorgas sejam casos específicos de cada projeto. As áreas de ocorrência desse tipo de licença são predominantes

Silveira, I.M. M., Santos, D.B., Costa, F.R., Soares, R. H. R.M, Gonçalves Junior, T.A., Pontes, C.S. 
na porção oriental do estado, em relação ao número de pedidos (Figura 5).

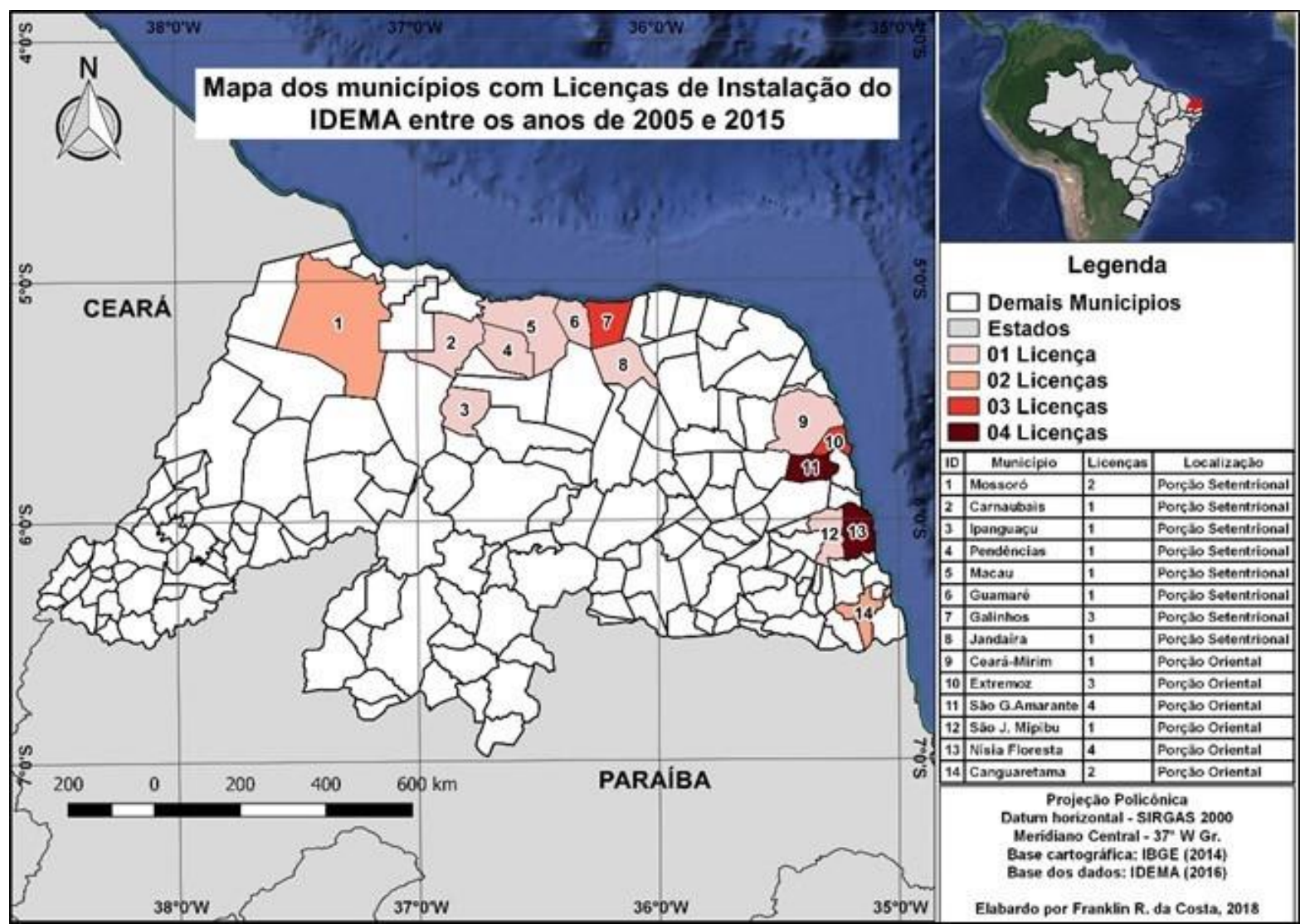

Figura 5. Representação espacial dos municípios detentores das Licenças de Instalação entre os anos de 2005 e 2015, de acordo com dados do Instituto de Desenvolvimento Sustentável e Meio Ambiente (IDEMA). Fonte: Pesquisa Documental - IDEMA - RN, 2016.

A quantidade de licenças expedidas por cidades foram: Porção oriental: Nísia Floresta (4), São Gonçalo do Amarante (4), Extremoz (3), Canguaretama (2), São José de Mipibú (1) e Ceará - Mirim (1); Porção setentrional: Galinhos (3), Mossoró (2), Guamaré (1), Carnaubais (1), Macau (1), Pendências (1), Jandaíra (1) e Ipanguaçu (1).

Percebe-se que, apesar do maior número de municípios que solicitaram a LI ser da Porção Setentrional (PS) do estado, a maior quantidade de solicitações foi observada na Porção Oriental (PO), sendo 11 e 15, respectivamente.

As Licenças de Regularização de Operação (LRO) podem ser concedidas quando um empreendimento já se encontra instalado e/ou em operação sem que tenha havido anteriormente a solicitação das licenças prévia e de instalação, ou seja, quando está atuando sem os licenciamentos obrigatórios. Os dados mostram que foram emitidas 66 licenças desse tipo, com destaque de expedições nos anos de 2009 e 2011, ambos com 11 licenças, sendo seguidos pelos anos de 2007, 2008 e 2013 onde foram outorgadas 9 licenças, distribuídas entre fazendas de micros, pequenos e médio portes. Durante o ano de 2005 não houve qualquer liberação de LRO. Entre os anos analisados não foi concedida nenhuma LRO para empresas de grande e excepcional porte (Figura 6).

Licenças do tipo LRO podem ser renovadas através de Licença Simplificada (LS) ou Licença de Operação (LO), dependendo do porte do empreendimento. Se for micro ou pequeno porte, a renovação se dá através da LS, se for de médio, grande ou excepcional porte será necessária à renovação através da LO (Figura 6). 


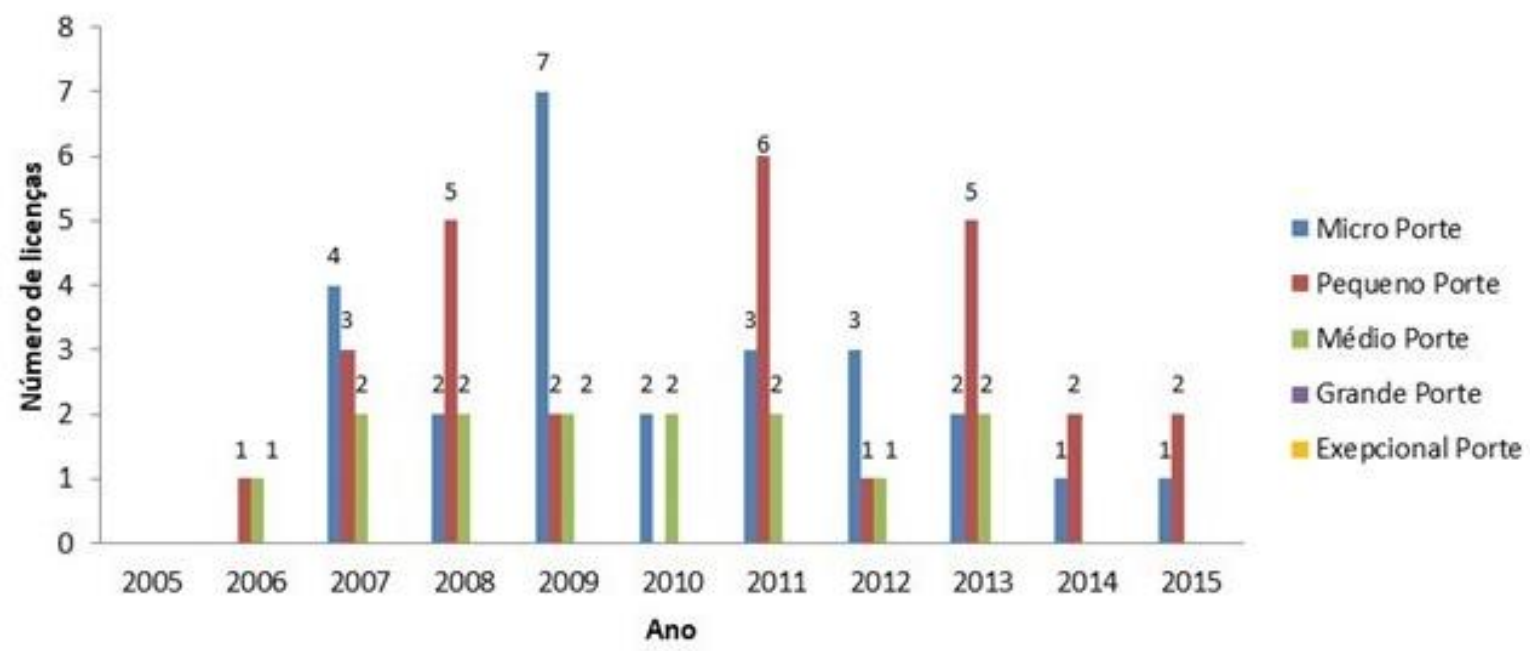

Figura 6. Licenças de Regularização de Operação expedidas pelo Instituto de Desenvolvimento Sustentável e Meio Ambiente (IDEMA) nos anos de 2005 a 2015 em razão do porte do empreendimento (Lei no 9.978/2015). Fonte: Pesquisa Documental - IDEMA - RN, 2016.

As áreas de ocorrência desse tipo de licença estão localizadas principalmente na porção oriental do estado (Figura 7). A quantidade de licenças expedidas por cidades foram: Porção oriental: Arês (11), Senador Georgino Avelino (9), Nísia Floresta
(6), Goianinha (6), Canguaretama (6), Tibau do Sul (5), São Gonçalo do Amarante (3), Ceará-Mirim (2), Baía Formosa (2), Natal (1), Extremoz (1) e Vila Flor (1); Porção setentrional: Carnaubais (4), Mossoró (3), Guamaré (2), Areia Branca (1), Apodi (1), Pendências (1), e Porto do Mangue (1).

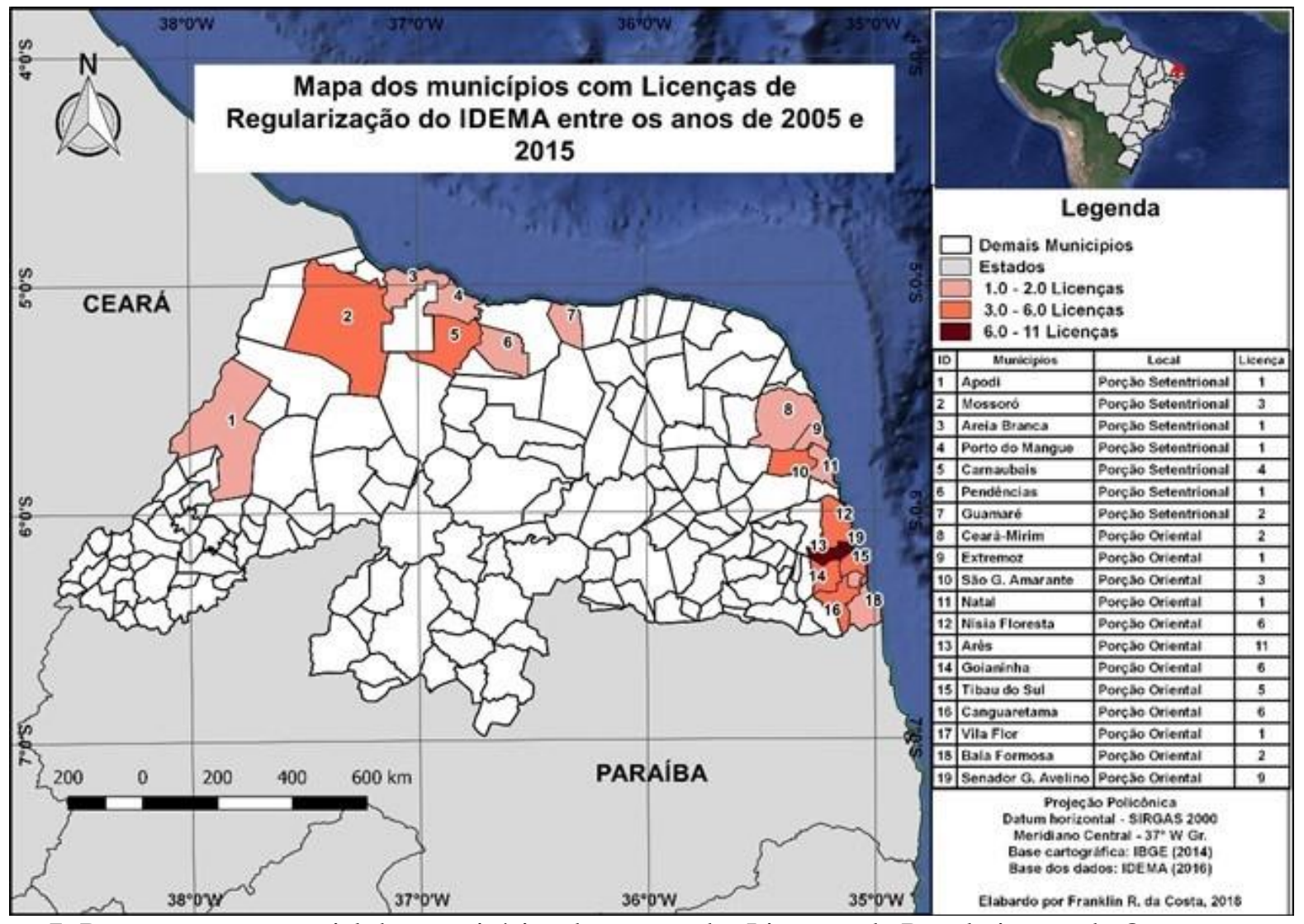

Figura 7. Representação espacial dos municípios detentores das Licenças de Regularização de Operação entre os anos de 2005 e 2015, de acordo com dados do Instituto de Desenvolvimento Sustentável e Meio Ambiente (IDEMA). Fonte: Pesquisa Documental - IDEMA - RN, 2016. 
De acordo com a Figura 7, percebemos que, assim como nas Licenças de Instalação, a maior quantidade de solicitações se deu na porção Oriental do Estado, mas, que nesse caso, apresentou também um maior número de municípios.

Com relação às Licenças Simplificadas (LS), que são especificas para empreendimentos de

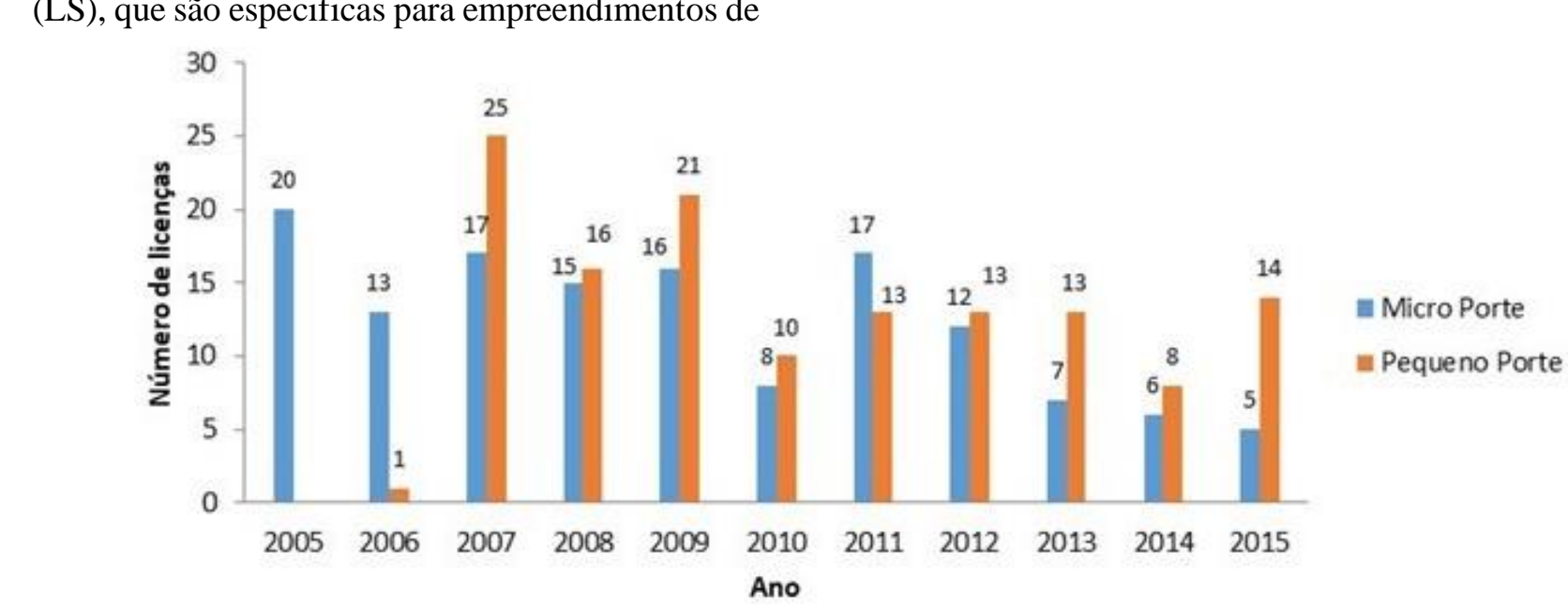

micro e pequeno porte, tiveram 270 licenças expedidas durante esse período de 11 anos. O destaque ocorreu no ano de 2007 com 42 outorgas ao todo, sendo 17 de micro porte e 25 de pequeno porte (Figura 8). Os anos de 2006 e 2014 foram os que apresentaram o menor número de licenças, onde foram registradas apenas 14 (Figura 8).

Figura 8. Licenças Simplificadas (LS) expedidas pelo Instituto de Desenvolvimento Sustentável e Meio Ambiente (IDEMA) nos anos de 2005 a 2015 em razão do porte do empreendimento (Lei nº 9.978/2015).Fonte: Pesquisa Documental - IDEMA - RN, 2016.

Das 270 LS expedidas, 59 foram renovações. Esse número é baixo se comparado com a quantidade total de LS expedidas pelo órgão, evidenciando que $78,15 \%$ dos produtores não tem a cultura de requerer a renovação. Hipoteticamente, isso ocorreu em função da falência dos empreendimentos, da falta de interesse e/ou da deficiência na fiscalização.

A Porção oriental do estado é a região que mais solicitou esse tipo de licença. As cidades detentoras de LS estão representadas espacialmente na Figura 9. Os números de licenças por cidade são: Porção oriental: Tibau do Sul (65), Arês (37), Nísia Floresta (30), Canguaretama (25), São Gonçalo do Amarante (17), Goianinha (15), Macaíba (13), Senador Georgino Avelino (11), Ceará-Mirim (7), Extremoz (6), Tangará (4), Vila Flor (2), São José de Mipibú (2), Maxaranguape (1), Pureza (1), Pedra Grande (1), Baía Formosa (1) e Nova Cruz (1); Porção setentrional: Mossoró (12), Guamaré (4), Pendências (4), Caiçara do Norte (3), Apodi (3), Macau (1), Ipanguaçu (1), Areia Branca (1), Governador Dix-Sept Rosado (1) e Grossos (1). 


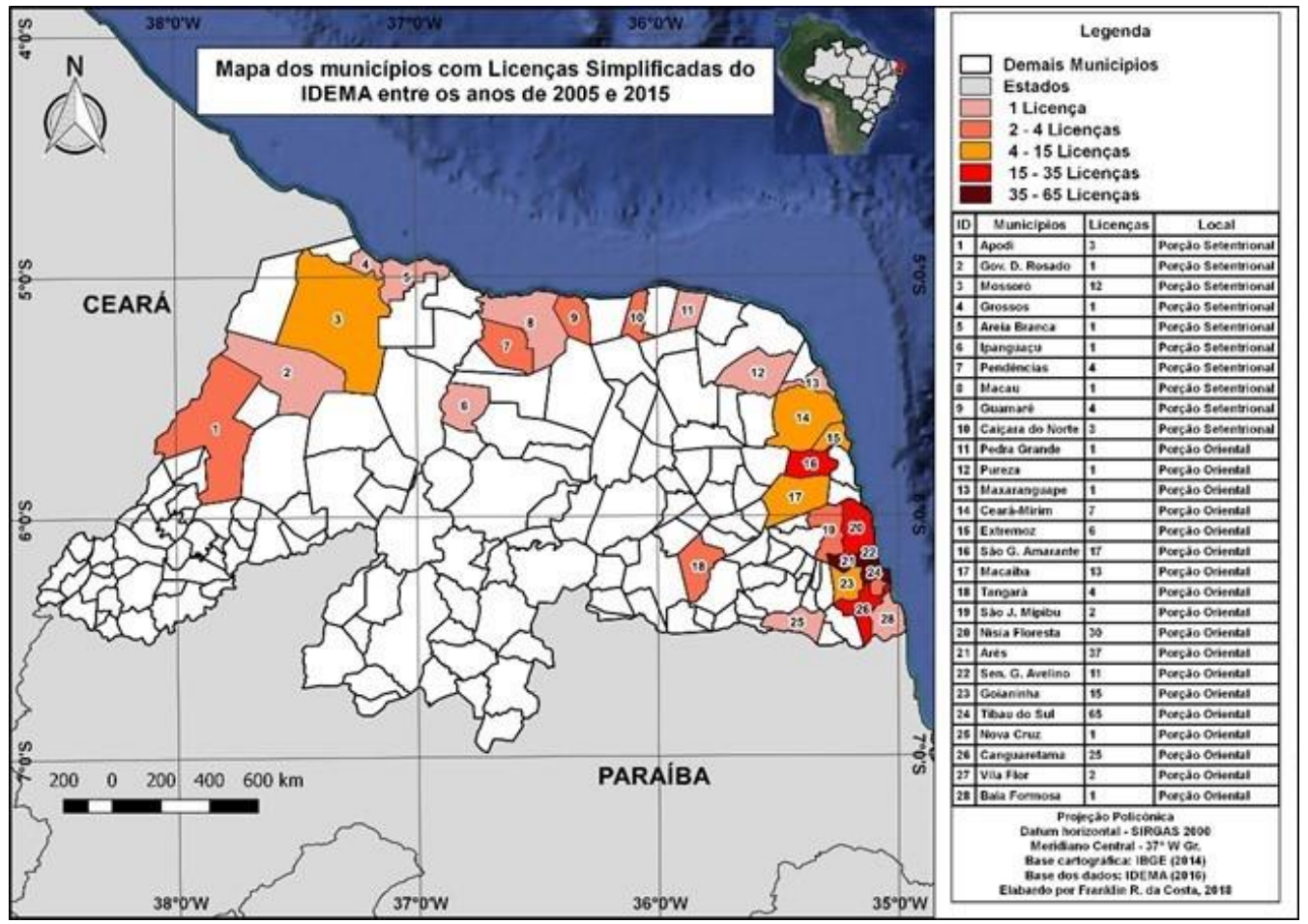

Figura 9. Representação espacial das cidades detentoras das Licenças Simplificadas entre os anos de 2005 e 2015, de acordo com dados do Instituto de Desenvolvimento Sustentável e Meio Ambiente (IDEMA). Fonte: Pesquisa Documental - IDEMA - RN, 2016.

Referente às Licenças de Operação (LO), no estado do Rio Grande do Norte, são ofertadas geralmente para empreendimentos de médio a excepcional porte, já que os portes menores recorrem a Licença Simplifica que é regulamentada pela Lei complementar estadual $n^{\circ} 272 / 2004$.

Foram emitidas 300 licenças entre 2005 e 2015, sendo predominantes as empresas de médio porte (Figura 10). O ano de 2006 apresentou o maior número de licenças (60) sendo quase o dobro do ano de 2008 que apresentou o segundo maior número de expedições (33). A grande quantidade de licença de operação (LO) evidencia uma maior ocorrência de empreendimentos de excepcional porte, 17 ao todo, o único ano em que não aparece esse tipo de porte é o de 2006.

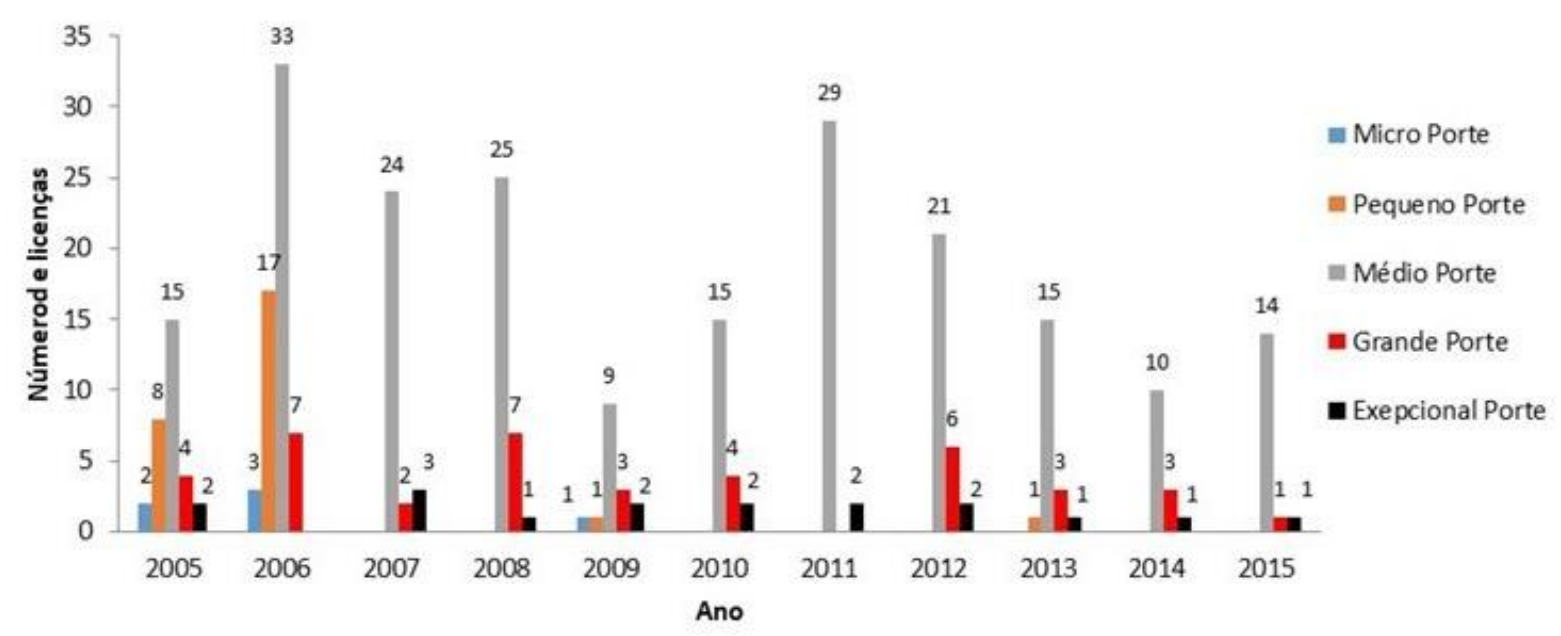

Figura 10. Licenças de Operação expedidas pelo Instituto de Desenvolvimento Sustentável e Meio Ambiente (IDEMA) nos anos de 2005 a 2015 em razão do porte do empreendimento (Lei n ${ }^{\circ}$ 9.978/2015). Fonte: Pesquisa Documental - IDEMA - RN, 2016.

Sobre as renovações das licenças, das 300 LO concedidas, 185 são de renovações. Esses dados demostram que os empreendimentos de porte maior manifestam uma preocupação com a 
conformidade das exigências legais, visto que, pouco mais da metade das licenças outorgadas foram referentes a renovações de licenças antigas.

A área do estado que apresentou maior número de Licenças de Operação foi a porção oriental do estado (Figura 11). A quantidade de licenças por cidade foi de: Porção oriental: São Gonçalo do Amarante (30), Canguaretama (24), Ceará- Mirim (23), Nísia Floresta (22), Arez (16),
Tibau do Sul (14), Extremoz (11), Macaíba (8), Senador Georgino Avelino (8), São José de Mipibú (6), Tangará (6), Natal (4), Goianinha (3), Baía Formosa (2) e Maranguape (1); Porção setentrional: Macau (33), Mossoró (25), Guamaré (20), Carnaubais (17), Pendências (12), São Bento do Norte (7), Galinhos (3), Areia Branca (2), Caiçara do Norte (1), Grossos (1) e Porto do Mangue (1).

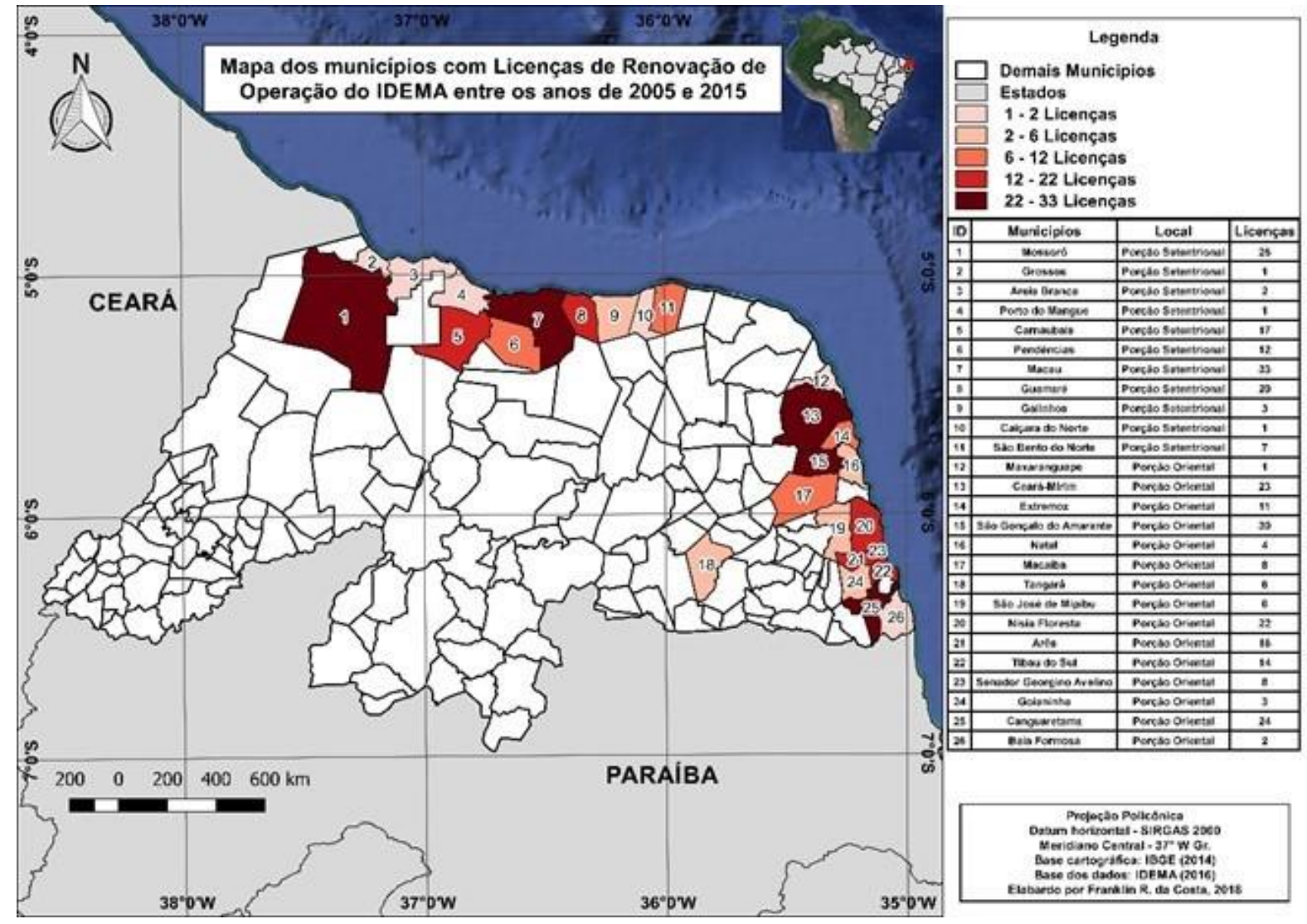

Figura 11. Representação espacial das cidades detentoras das Licenças de Operação entre os anos de 2005 e 2015 , de acordo com dados do Instituto de Desenvolvimento Sustentável e Meio Ambiente (IDEMA). Fonte: Pesquisa Documental - IDEMA - RN, 2016.

Referente à Licença de Alteração (LA), foram expedidas 20 licenças durante os 11 anos analisados, apresentando como as empresas de porte médio como predominante, totalizando 9 licenças. Poucas licenças foram expedidas a cada ano, sendo os anos de 2006, 2010 e 2011 os com maiores números de LA outorgados (3). Observou- se que essa é a única modalidade de licença que não é expedida desde 2012 (figura 12).

Esse tipo de licença não existe a necessidade da renovação, visto que é um tipo especial, requerida somente quando se pretende alterar o tamanho da área de exploração (Figura 12). 


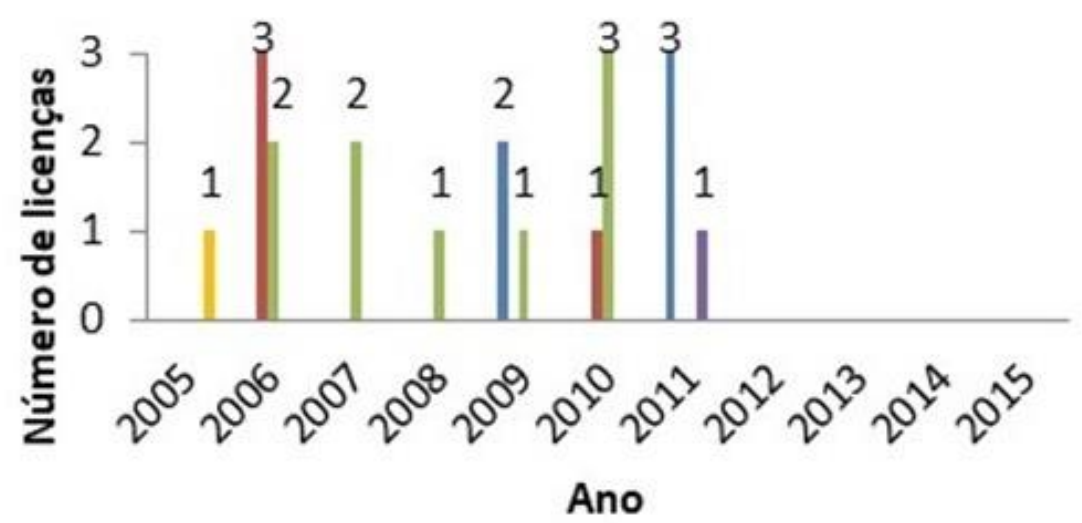

Micro Porte

Pequeno Porte

Médio Porte

Grande Porte

Exepcional Porte

Figura 12. Licenças de Alteração expedidas pelo Instituto de Desenvolvimento Sustentável e Meio Ambiente (IDEMA) nos anos de 2005 a 2015 em razão do porte do empreendimento (Lei no 9.978/2015). Fonte: Pesquisa Documental - IDEMA - RN, 2016.

A área do estado que apresentou maior número de LA foi a porção oriental. A quantidade de licenças por cidade foi de: Porção oriental: Nísia Floresta (3), São Gonçalo do Amarante (2), Ceará- Mirim (2), Goianinha (1), Tibau do Sul (1), Extremoz (1), São José de Mipibú (1), Natal (1), Macaíba (1) e Pedra Grande (1); Porção setentrional: Mossoró (2), Macau (1), Galinhos (1), Guamaré (1) e Pendências (1).

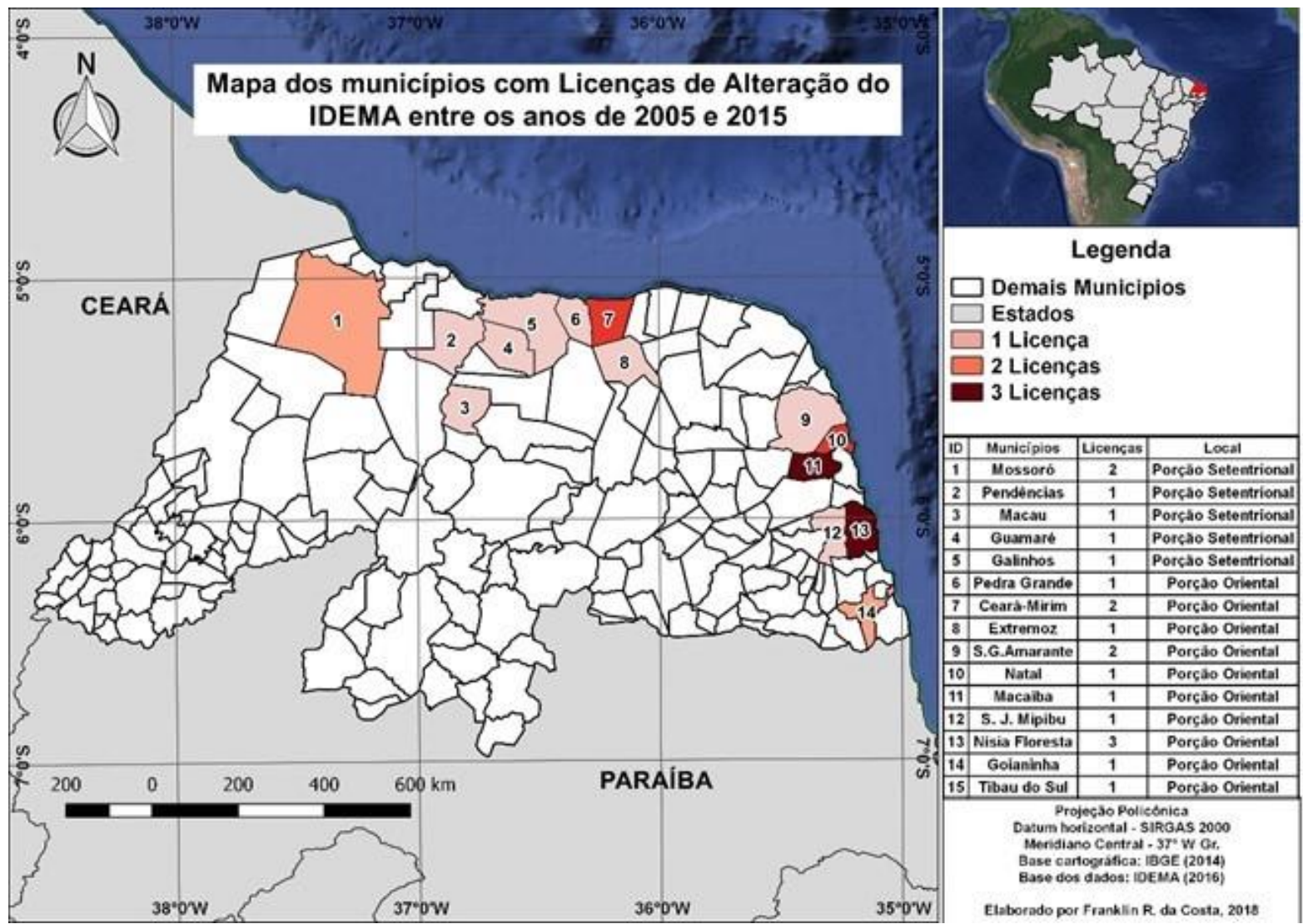

Figura 13. Representação espacial das cidades detentoras das Licenças de Alteração entre os anos de 2005 e 2015, de acordo com dados do Instituto de Desenvolvimento Sustentável e Meio Ambiente (IDEMA). Fonte: Pesquisa Documental - IDEMA - RN, 2016.

Ao analisar os dados, observou-se que somente 250 empreendimentos $(35,81 \%)$ buscaram uma renovação de suas licenças (IBAMA, 2005; Mialhe et al., 2013). Alves e Braun (2013) afirmam que a passividade dos órgãos ambientais e a burocracia pode ser a razão para o grande número de fazendas irregulares, já que essa inércia, muitas vezes, força os produtores a agirem por conta própria e assumir o ônus da implantação de um projeto, mesmo sem ter recebido as licenças ambientais, causando prejuízos e insegurança aos

Silveira, I.M. M., Santos, D.B., Costa, F.R., Soares, R. H. R.M, Gonçalves Junior, T.A., Pontes, C.S. 
investidores. Ribeiro et al. (2014) afirmam que, na prática, isso significa que a qualidade dos camarões produzidos, em termos de segurança alimentar, e os impactos socioambientais associados a esta atividade, não são monitorados, mitigados ou coibidos.

O caso é ainda mais preocupante se essas fazendas irregulares estiverem enfrentando alguma enfermidade. De acordo com Goularti Filho e Ronçani (2015), as patologias são combatidas com o uso de potentes fármacos que resolvem temporariamente o problema, porém fragilizam ainda mais o organismo dos animais, que passam a desenvolver novas e complexas enfermidades mais difíceis de serem isoladas e combatidas. Isto gera um problema para a atividade, mas uma oportunidade de mercado para a indústria química que fornece vacinas e medicamentos. Portanto, combater as enfermidades na aquicultura tornou-se também um negócio que envolve uma cadeia de produtores e fornecedores de produtos químicos.

Uma das doenças mais agressivas que a carcinicultura brasileira enfrentou foi o Vírus da Mionecrose Infecciosa (IMNV), que causa a mortalidade de $40 \%$ a $60 \%$ de animais juvenis e sub-adultos de L. vannamei, cultivados em cativeiro, com perdas estimadas em milhões em 2003 (Nunes et al, 2004). Segundo a ABCC, apenas no ano de 2004, as perdas relacionadas a doenças foram estimadas em US\$ 20 milhões, sendo essa uma das principais causas de redução da produção nacional na época (Pereira et al, 2008). Além disso, a Lei Antidumping dos Estados Unidos, aplicada contra o camarão de vários países, inclusive o do Brasil, no ano de 2005, fez o país perder o seu principal mercado exportador (Alves e Braun, 2013), iniciando a crise nacional do setor.

Outro fator impactante ocorreu no ano de 2008 e está relacionada à ocorrência de uma anormalidade na precipitação pluviométrica, acarretando enchentes que inundaram grande parte das cidades do estado do Rio Grande do Norte, destruindo inúmeras fazendas de camarão. Rocha (2011) afirma que os produtores perderam em estoque de produção 1.400 toneladas de camarão e 720 mil toneladas de peixes do tipo tilápia. Ainda de acordo com o autor, cerca de $90 \%$ da área destinada ao cultivo da carcinicultura nos municípios de Pendências, Carnaubais, Porto do Mangue e Macau (correspondendo a 30\% da área de todo o RN) foram inundados.

As enfermidades, em associação com o corte verbas de financiamento, desvalorização do dólar frente ao real e os alagamentos, ocasionaram uma queda nas exportações gerando, entre os anos 2004 - 2009, um prejuízo aos produtores na casa dos milhões (Rocha, 2011). A situação relatada pelos representantes da atividade de carcinicultura e pela literatura especializada, mostram que houve um baixo crescimento da carcinicultura brasileira entre os anos 2004 e 2009 (Pereira et al., 2008), em função da incidência do Vírus da Mionecrose Infecciosa (IMNV). Contraditoriamente, observamos que a maioria das licenças para o Rio Grande do Norte foram expedidas nos anos de 2006 a 2009, quando nesses anos devia-se esperar uma queda no número de licenças. Foi detectada uma menor quantidade de emissões de licenças em 2005, com 55 licenças, e logo após, os anos mais críticos foram 2010, 2013, 2014 e 2015 (Figura 1). A maior quantidade de solicitação de outorga ocorreu no ano de 2006, com 88 licenças, sendo 60 do tipo Licença de Operação - LO (Figura 10). Em segundo lugar encontram-se empatados os anos de 2007 e 2011 com 83 emissões. Em 2007, sobressaiu-se a licença do tipo LS com 42 expedições (Figura 8). Já no ano de 2011, os destaques foram as licenças do tipo LO com 31 expedições LO (Figura 10) e LS com 30 (Figura 8).

$\mathrm{O}$ aumento de licenças expedidas constatado posteriormente às dificuldades vivenciadas pela atividade em 2004 pode ser decorrente da morosidade na avaliação dos projetos de licenciamento por parte do órgão ambiental, uma vez que a demora na avaliação de um pedido de licença pode demorar por volta de 04 (quatro) anos aguardando a avaliação dos órgãos de licenciamento ambiental do estado (Alves e Braun, 2013).

Partindo desse princípio, as licenças outorgadas no período entre os anos de 2004 e 2009 , hipoteticamente podem ter sido solicitadas anteriormente ao ano de 2004, vindo a aparecer nos dados oficiais algum tempo depois. Os problemas enfrentados pela carcinicultura levaram a um decréscimo na produção. Entre os anos de 2003 e 2012, dos 10 maiores produtores mundiais de camarão, o Brasil foi o único país que apresentou uma redução de produção, com 16,84\% a menos que o ano de 2002 (FAO, 2014). Durante os anos analisados, a produtividade passou de 4.333 $\mathrm{Kg} / \mathrm{Ha} / \mathrm{ano}$ em 2005 para $3.863 \mathrm{Kg} / \mathrm{Ha} / \mathrm{ano}$ em 2013 (FAO, 2014).

No que diz respeito ao valor do camarão, a FAO (2016) anunciou que os preços do camarão caíram significativamente ano a ano, a nível global. No primeiro semestre de 2015 , o preço do camarão caiu de $15 \%$ a $20 \%$, afetando negativamente os produtores e beneficiando os consumidores, uma vez que a disponibilidade per capita anual dos crustáceos cresceu de 0,4 kg em 1961 para $1,8 \mathrm{~kg}$ em 2015. Rocha (2016) alerta sobre o fato de que, 
apesar de apresentar uma recuperação, a carcinicultura brasileira nunca conseguiu voltar ao patamar de 2003 (90.190 t). Na pior fase, o país produziu $60.000 \mathrm{t}$, no ano de 2014 chegou a 85.000 $\mathrm{t}$ e em 2015 decaiu novamente, atingindo $76.000 \mathrm{t}$. Para o ano de 2016, o autor prevê mais uma redução, dessa vez para 70.000 t devido uma nova disseminação da Mancha Branca no Ceará, principal produtor nacional. Ainda segundo o autor, a melhor forma de manter a carcinicultura brasileira equilibrada é a retomada do crescimento das exportações, porém sem descuidar do marcado nacional conquistado. De acordo com a FAO (2018) Camarões são "commodities" fortemente comercializados, representando o segundo principal grupo de espécies aquáticas exportadas em termos de valor. Países da América Latina e do Oriente e Sudeste Asiático respondem de longe pela maior parte da produção, mas uma grande proporção do consumo ocorre nos mercados desenvolvidos.

Problemas na qualidade do ambiente de cultivos são considerados fatores estressores para o camarão cultivado, levando ao adoecimento do animal e fazendo com que o produtor busque alternativas imediatas de mitigação. Carvalho et al. (2017) detectaram diferentes ecotipos e fatores de virulência de Salmonella spp. em fazendas de carcinicultura do Ceara, afirmando que a presença desses genes de virulência nas amostras isoladas das fazendas evidencia $o$ potencial para desencadear eventos de salmonelose relacionados ao consumo de camarão. O biomonitoramento dessas fontes de contaminação deve ser incentivado como medida protetiva, minimizando os riscos do ponto de vista sanitário e das perdas econômicas para o setor da carcinicultura.

De acordo com Ribeiro et al. (2014), a legislação brasileira é claramente omissa no controle do uso de drogas no cultivo, uma vez que não possui regras específicas, sendo desconsiderados os possíveis impactos negativos da utilização de compostos como antibióticos e hormônios, na fauna e na flora dos corpos receptores de efluentes. Vicente et al. (2017), afirma que a carcinicultura é uma forma importante de fornecer matéria-prima para a indústria alimentícia e a busca de lucratividade desse tipo de atividade, acrescida muitas vezes da ineficiência dos órgãos de governo nas atividades do licenciamento e fiscalização, e a não observância e/ou a permissividade das legislações ambientais podem levar a uma série de impactos socioeconômicos e ambientais negativos.

Devemos considerar que é necessário o cuidado com o ambiente de cultivo, como também com o seu entorno, sendo de fundamental importância respeitar e cumprir os preceitos ambientais contidos nas legislações ambientais de âmbito estadual e federal, inerentes à área de carcinicultura, evitando assim possíveis perdas na produtividade a curto, médio e longo prazo. A fiscalização e o acompanhamento dos cultivos pelos órgãos ambientais ocorrem de forma ainda incipiente, o que leva o produtor a relevar os aspectos legais do desenvolvimento da atividade, o que pode levar a um aumento no custo ambiental do camarão produzido. A busca do licenciamento ambiental é essencial para o desenvolvimento de uma carcinicultura responsável e para a manutenção dessa atividade de grande importância econômica para o estado do Rio Grande do Norte.

\section{Conclusões}

A avaliação dos documentos indicou uma flutuação na quantidade de licenças expedidas, sendo a maioria registrada entre os anos de 2006 a 2009, período relatado como mais crítico da carcinicultura nacional (2004 a 2009). Grande parte das licenças concedidas foram do tipo de Operação, com 300 licenças concedidas e do tipo Simplificada com 270 emissões, apresentando predominância de empreendimentos de médio porte e com localização na região oriental do estado.

Verificou-se também que existe, por parte dos produtores, morosidade na busca da renovação das suas licenças, uma vez que este estudo identificou 448 empreendimentos (64,18\%) atuando com suas licenças irregulares. Essa constatação causa preocupação, tanto com a qualidade do camarão produzido como com a seguridade do meio ambiente em que as fazendas estão inseridas.

\section{Agradecimentos}

$\mathrm{O}$ presente trabalho foi realizado com apoio da Coordenação de Aperfeiçoamento de Pessoal de Nível Superior - Brasil (CAPES) Código de financiamento 001. Ao PRODEMA/UFRN, por aportar esta pesquisa no âmbito do curso do mestrado. Ao Instituto de Desenvolvimento Sustentável e Meio Ambiente do Rio Grande do Norte (IDEMA-RN) pela cessão dos documentos que possibilitaram esta pesquisa.

\section{Referências}

Alves, A. K., \& 2013, B. M. B. S. . Consequências da Ação antidumping sobre a produção de 
camarão na microrregião do Litoral de Aracati - CE, na perspectiva dos elos da cadeia produtiva. Revista Tecnologia $e$ Sociedade. 9, 16(6), [Google Scholar]

Carvalho, F. C. T., Rodriguez, M. T. T., Menezes, F. G. R., Sousa, O. V., Hofer, E., \& Vieira, R. H. S. F. (2017). . : and. [Google Scholar]

Ecotypes, . virulence factors of Salmonella spp. detected in shrimp farms in State of Ceara. Brazil. Acta Scientiarum. Biological Sciences, 39(4), 549-546. [Google Scholar]

Filho, G., Ronçani, A., \& L D, (2018). Carcinicultura em Santa Catarina: da euforia desregulada à crise generalizada. Historia Ambiental, Latinoamericana y Caribeña, 8(1), 67-91. [Google Scholar]

Kubitza, F. (2015). Aquicultura no Brasil. Panorama da aquicultura. , 25(150), 1023. [Google Scholar]

Mialhe, F., Gunnel, Y., \& Mering, C. (2013). The impacts of shrimp farming on land use, employment and migration in Tumbes, northern Peru. Ocean \& Coastal Management, 72, 1-12. [Google Scholar]

Nunes, A. J. P., Martins, P. C. C., \& Gesteira, T. C. V. (2014). Carcinicultura ameaçada. Produtores sofrem com mortalidades decorrentes do vírus da mionecrose infecciosa (IMNV. Panorama da Aquicultura, 83, 37-51. [Google Scholar]

Paez-Osuna, F. (2001). The environmental impact f shirmp aquaculture: Causes, effects and mitigating alternatives. Enrionmental Magement, 1, 131-140. [Google Scholar]

Pereira, A. M. L., Mendes, E. S., \& Gesteira, T. C. V. (2008). Mionecrosis infecciosa viral (IMNV) y sus implicaciones en los cultivos de camarones brasileños. In: MORALES, V; CUÉLLAR- ANJEL, J. Guia TécnicaPatología e Inmunología de Camarones
Penaeidos, Programa CYTEC Red II-D vannamei, Panam, 8, [Google Scholar]

Reis, J. N. P. (2008). Sustentabilidade na Produção de Camarão: O Caso da Comunidade de Requenguela, no Município de Icapu. Ceará. Revista Econômica do Nordeste, 39, 251262. [Google Scholar]

Ribeiro, L. F., Souza, M. M., Barros, F., \& Hatje, V. (2014). Desafios da carcinicultura: aspectos legais, impactos ambientais e alternativas mitigadoras. Journal of Integrated Coastal Zone Management, 14, 365-383. [Google Scholar]

Salim, J. (2002). Panorama da carcinicultura potiguar: sua importância e perspectivas de crescimento. Revista Panorama da Aquicultura, 12, 38-40. [Google Scholar]

Sousa, A. M. V., Bezerra, A. C. V., Lyra, T. M., \& Albuquerque, M. S. V. (2017). Problemas e conflitos socioambientais no litoral do Município de Goiana, Pernambuco. Revista Brasileira de Geografia Física 10. , 6, 19341947. Google Scholar

Sousa, R. S., Valladares, G. S., \& Espindola, G. M. (2016). Mapeamento multitemporal do uso e cobertura da terra da planície costeira do estado do Piauí. Revista Brasileira de Geografia Física 09. , 05, 16061620. [Google Scholar]

Damaceno, T. E. F., Araújo, M. N., \& I F, (2019). Trajetória Tecnológica e Sustentabilidade Ambiental na Cadeia de Produção da Carcinicultura no Brasil. Revista de Economia e Sociologia Rural, 57(1), 93108. [Google Scholar]

Vicente, D. N., Mello, F. A., Rossi e Silva,, , \& R C, (2016). Carcinicultura Brasileira: Impactos e Ações Mitigadoras. Colloquium Agrariae, 12(2), 58-61. [Google Scholar] 